\title{
Illusions of Resilience? An Analysis of Community Responses to Change in Northern Norway.
}

\author{
Helene Amundsen ${ }^{1}$
}

\begin{abstract}
This article contributes to our understanding of community resilience. Community resilience is the ability of a community to cope and adjust to stresses caused by social, political, and environmental change and to engage community resources to overcome adversity and take advantage of opportunities in response to change. Through an analysis of local responses to multiple challenges, six dimensions of community resilience were found in one village in northern Norway. These dimensions; community resources, community networks, institutions and services, people-place connections, active agents, and learning; are activated in processes and activities in the village to respond to current challenges. Although this corroborates findings from other community resilience research, this research suggests that community resilience is both complex and dynamic over time. Although communities may consider themselves resilient to today's challenges, the rate and magnitude of expected systemic global changes, especially climate change, means that future resilience cannot be taken for granted. This work concludes that there is a risk that community resilience may be an illusion, leading to complacency about the need for adaption to multiple factors of change. Hence, the ability of communities to actively engage in reflexive learning processes is of importance for both adaptation and future resilience.
\end{abstract}

Key Words: adaptation; climate change; community resilience; adaptation; local development; northern Norway

\section{INTRODUCTION}

Community resilience is the ability of a community to cope and adjust to stresses caused by social, political, and environmental change and to engage community resources to overcome adversity and take advantage of opportunities in response to change (Buikstra et al. 2010, Magis 2010, Ross et al. 2010). Community resilience depends on the ability to respond and adapt to the continuous changes occurring in communities (Magis 2010). The concept is analytically useful because it captures the collective dimension and the dynamic properties of the way in which communities are adapting to changes. Here, community refers to a group of people in a geographical location, such as a village.

The adaptive capacity of a community is directly related to its resilience, as one of three fundamental properties of a resilient system (Adger et al. 2011, Berkes et al. 2003). A resilient community is expected to be well suited to adapt to current and future changes, including social, economic, environmental, and cultural changes. However, the reported changes in environmental and socioeconomic conditions are unprecedented, particularly in the Arctic, according to a number of reports (Arctic Climate Impact Assessment 2005, Arctic Monitoring and Assessment Programme 2011a, Arctic Council 2004). Furthermore, in the context of climate change, the Arctic has been highlighted as a region particularly vulnerable to climate change (Anisimov et al. 2007). Therefore, despite the historical and current resilience of a community, it is timely to ask whether such resilience will be applicable in the context of future global changes, particularly to the impacts of climate change. Furthermore, there is also a question of how we comprehend and analyze resilience in this context. Although communities may perceive and exhibit resilience at the local scale, they are nonetheless part of a global system and have to respond to changes affecting them through this connectedness. Globalization processes in particular can influence the resilience of communities (Leichenko and O'Brien 2008). Anderies and Jansson (2011) argue that in isolation local communities can be robust, but their linkages to processes at the higher levels, including the global, have consequences for their robustness.

In analyzing the factors that influence community resilience, our work is a contribution to this emerging research field. The study is based on empirical findings from a coastal village on the island of Senja in northern Norway, an example of a community actively seeking to overcome major challenges. The findings expand on current community resilience research (Buikstra et al. 2010, Magis 2010, Ross et al. 2010) by showing that reflexive learning is an added important dimension. This is particularly true with respect to future community resilience.

\section{COMMUNITY RESILIENCE}

The concept of resilience has multiple applications, including in disaster management (Manyena 2006, Norris et al. 2008), psychology and well-being (Buikstra et al. 2010, Luthar and Cicchetti 2000), and social-ecological systems (Gunderson and Holling 2002), with responding to adversity as the common focus. The insights from this wide scientific literature are increasingly compared to improve the application of the concept; for instance, in the review of the application of resilience to the areas of environment, well-being, and disaster 
Table 1. Three approaches showing factors important for community resilience.

\begin{tabular}{lll}
\hline \hline Social networks and support & Community resources (natural, human, cultural, & People-place connections \\
Positive outlook & financial, built, political, social capitals/resources) & Knowledge, skills, and learning \\
Learning & Development of community resources & Community networks \\
Early experiences & Engagement of community resources & Engaged governance \\
Environment and lifestyle & Active agents & Diverse and innovative economy \\
Infrastructure and support services & Collective and strategic action & \\
Sense of purpose & Equity & \\
Diverse and innovative economy & Impact & \\
Embracing differences & & \\
Beliefs & & (Ross et al. 2010) \\
Leadership & (Magis 2010) \\
\hline (Buikstra et al. 2010) &
\end{tabular}

research by Brown and Westaway (2011). Their review draws from these diverse areas of research to argue in favor of including subjective and contextual factors to resilience, and of understanding the interlinkages between the factors that are of relevance for resilience. Various approaches have been taken to include subjective dimensions within the resilience and adaptation research, including well-being (Coulthard 2012) and values (O'Brien and Wolf 2010). This new focus on subjective and contextual aspects of resilience is relevant for the people-place connections of our work.

Here, we take the social-ecological systems approach as a starting point, where the resilience concept is commonly defined as the ability of a system to sustain or absorb the consequences of a shock while keeping the function and form of the system (Chapin et al. 2004, Gunderson and Holling 2002, Walker et al. 2004). The concept has been applied to analyzing social ecological systems (SES), both theoretically (Folke 2006) and applied (Berkes and Jolly 2001, Forbes et al. 2009). One principal assumption is that the only way to build a sustainable society is through the understanding of social and ecological systems as inseparable (Berkes et al. 2003). The properties of the resilience of an SES have been defined as "(1) the amount of change the system can undergo and still retain the same controls on function and structure, (2) the degree to which the system is capable of self-organization, and (3) the community's ability to build and increase its capacity for learning and adaptation" (Berkes and Jolly 2001:2). An SES approach takes a nonlinear view of systems development, exemplified by the adaptive cycle of the four phases-exploitation, conservation, release, and reorganization - through which the system either returns to the state it started from, or have flipped to a new cycle (Gunderson and Holling 2002). In the working of this cycle, particularly (3) above (learning and adaptation) is important for our work.

The meaning of adaptation ranges from the general definition as a process of change to a specific definition in relation to climate change as "adjustment in natural or human systems to a new or changing environment" (Intergovernmental Panel on Climate Change (IPPC) 2007), as discussed by Orlove (2009).
The IPCC definition reduces adaptation to a response to external climate stimuli, which does not take into account the multiple impacts of other factors (McCarthy and Martello 2005, Wilbanks and Kates 2010). A much broader definition is used in cultural geography, where adaptation has been applied to understand how cultures, individuals, and societies are responding to changes (Denevan 1983). From this understanding, adaptation is here defined as the process of responding to interlinked changes in both internal and external factors that affect communities. Local communities are continuously responding to the challenges and opportunities that they perceive and experience, and adaptation to climate change cannot be separated from adaptation to other challenges or ongoing processes (O'Brien et al. 2004a, Hovelsrud and Smit 2010, Wilbanks and Kates 2010).

To uncover the aspects that constitute community resilience, Buikstra et al. (2010) identify 11 components of community resilience in a rural community in Australia based on individuals' perceptions of resilience. Ross et al. (2010) develop six indicators of social resilience at the regional level in Australia. These two sets of components overlap somewhat with the dimensions of community resilience developed in a study in the United States (Magis 2010). Table 1 below gives an overview of the three sets of factors as presented in these studies. The factors of community resilience that they identify are similar, but with some differences. Whereas Magis (2010) focuses on resources and action, both Buikstra et al. (2010) and Ross et al. (2010) emphasize social values in the community. This difference can mainly be attributed to the various methods used; the Magis (2010) study is mainly based on expert evaluation, whereas both Buikstra et al. (2010) and Ross et al. (2010) present perceptions of inhabitants.

These dimensions of community resilience overlap with the factors which are important for adaptive capacity, and which are enacted through adaptation. Focusing on institutions, Gupta et al. (2010) found six dimensions relevant for adaptive capacity of institutions, including learning capacity, leadership, and resources, which are all noted in Table 1. Nelson et al. (2007) attribute adaptive capacity mainly to 
Fig. 1.Location of Senja: i) detail of the island Senja, and ii) location of Senja in northern Europe.

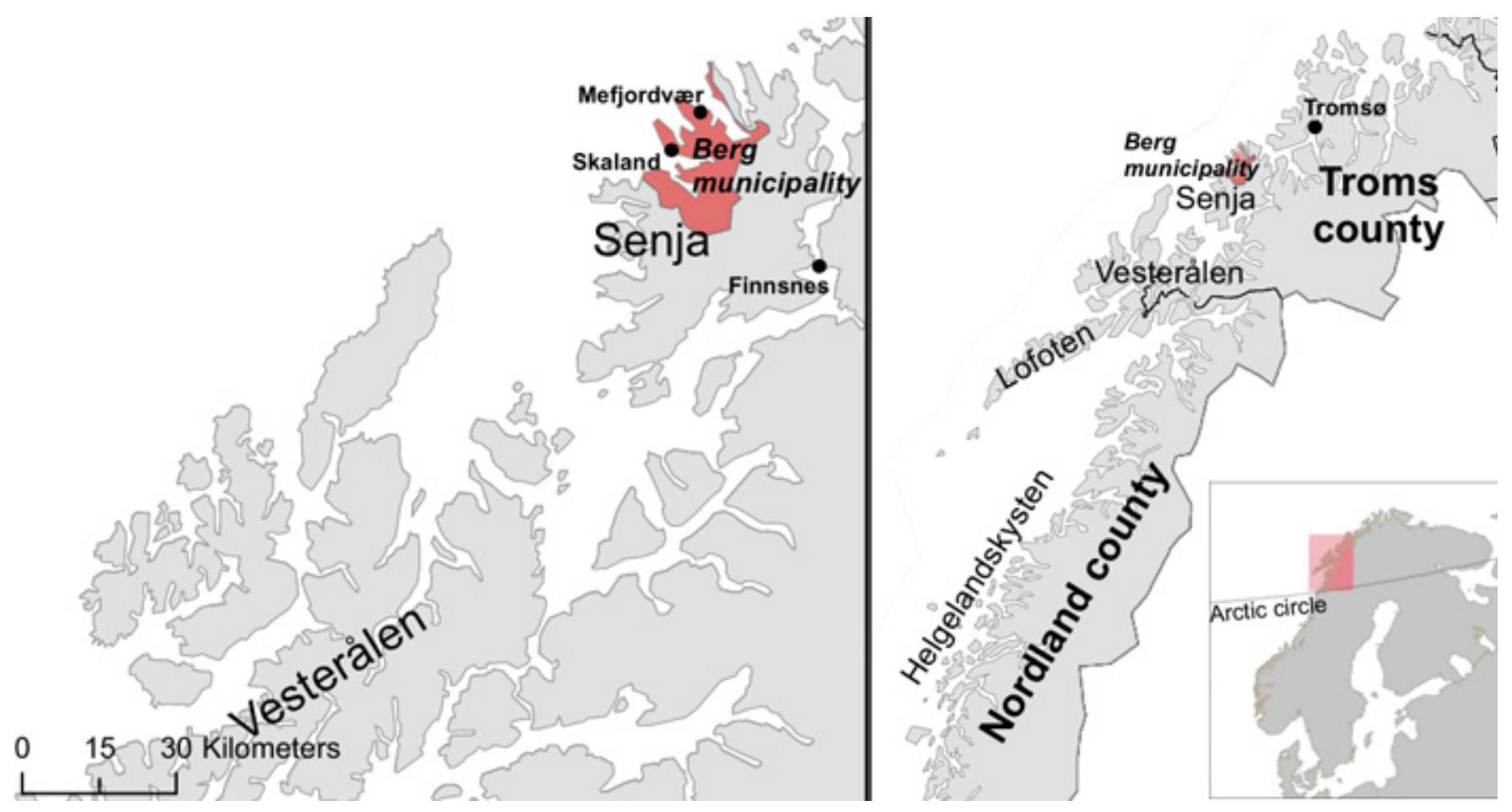

Map source: Statens kartverk (Norwegian Mapping Authority); adapted by Romstad.

resources, whereas Buikstra et al. (2010), Magis (2010) and Ross et al. (2010) all include a broader range of dimensions in their conceptualization of community resilience.

\section{ARCTIC CONTEXTS}

The aims for this research were to gain an understanding of the factors important for community resilience in a specific village, and to analyze this in the context of local adaptation to future global changes, particularly climate change. This particular work is included within a larger research project aimed at understanding how communities are adapting to changing social, political, economic, environmental, and climatic conditions, and what this means for our understanding of climate change adaptation. The larger project covers two municipalities in northern Norway, but for this particular study, one village was selected to focus on current processes of adaptation.

The village of Senja is located in the Arctic (Fig. 1). Arctic communities are expected to be significantly affected by climate change, directly and indirectly through processes at different temporal and spatial scales, and must respond to corresponding challenges and changes (Arctic Climate Impact Assessment 2005, Arctic Monitoring and Assessment Programme 2011b, Chapin et al. 2004, Crate 2008, Ford et al. 2006a, $b$, Hovelsrud and Smit 2010, Keskitalo 2008, Krupnik and Jolly 2002, Arctic Council 2004). The specific local conditions relevant for understanding climate change adaptation are addressed in Hovelsrud et al. (2010) who investigates adaptation to combined climatic and nonclimatic exposure sensitivities in coastal communities in northern Norway; Keskitalo (2004) analyzes the vulnerability of forestry sector in northern Sweden; Ford et al. (2006b) assesses the vulnerability of communities in the Canadian Arctic; and Tyler et al. (2007) analyzes reindeer herding and the consequences for Sámi communities. These case studies increase the understanding of adaptive capacity and adaptation processes at the local level. It follows from these empirical studies in communities across the Arctic that the wider and indirect implications of climate change combined with other challenges at the community level must be taken into account when investigating adaptation (see also Adger 2006, Belliveau et al. 2006, McCarthy and Martello 2005, O'Brien et al. 2004a, Wilbanks and Kates 2010). Research find that local communities do not differentiate between the suite of challenges they at any time are faced with and adapting to, including social, economic, and climatic (Smit and Wandel 2006). Hence, climate change is but one challenge requiring adaptation in communities (West and Hovelsrud 2010). 
Norway as a country is perceived to be resilient to climate change given a range of factors, such as the economy and available resources, but when focusing on certain sectors, regions, communities, and social groups, this picture becomes much more nuanced (O'Brien et al. 2004b). Cases from northern Norway support this. For instance, fisheries emerge as a statistically insignificant sector with respect to the regional employment statistics. However, in some municipalities, the fisheries directly employs up to a third of the workforce and is thus the single most important sector (West and Hovelsrud 2008). It has also been found that the combination of exposure sensitivities that communities are subject to together creates a more complex picture to adapt to, than focusing on one single factor (Hovelsrud et al. 2010). Yet the complacency regarding the ability to adapt is persistent, and there are few reflections on the limits to adaptation (O'Brien et al. 2006).

For northern Norway, climate models project higher average temperatures throughout the year, with most warming in the winter; and shifts in the seasons, with winters arriving later in the year. Increased precipitation has already been observed and by the year 2100 precipitation during the summer period is projected to increase by $13 \%$, along with an increase in extreme precipitation (Førland et al. 2007, RegClim 2005). However, compared with the other challenges facing the village of Senja, such as demographic changes, changes in the climate may seem insignificant. In addition, people in the region are accustomed to adapt to significant variations in the weather. Nevertheless, the direct and indirect consequences of climate change are expected to add an additional dimension to adaptation challenges in the region (Hovelsrud et al. 2010, West and Hovelsrud 2010).

The Norwegian government seeks to ensure equity and equal living conditions across the country, to maintain the current population structure and settlement patterns, and "to facilitate real freedom of choice in respect of where to live" (Government of Norway 2009, Kommunal-og Departmentet 2009:6). The aspects that determine where people settle in Norway include "quality housing, the availability of efficient services, proximity to family, community feeling and positive environmental benefits" (Kommunal-og Departmentet 2009:6). The policy vision is to ensure the viability of small communities, or "lights in all the houses" (Pedersen 2008). The municipalities, i.e., local governments, play an important role in achieving national policy goals as they are the local providers of public welfare services such as health care, child care, education, social services, spatial planning and local infrastructure, and as such represent a significant societal pillar (Bjørnå and Aarsæther 2010, Hovik and Reitan 2004). Some municipalities are more proactive than others, and take on extra responsibilities regarding local development and facilitating business development (Bjørnå and Aarsæther 2010). Furthermore, the municipalities have been singled out by the national government as arenas for climate change adaptation within their current areas of responsibilities (Amundsen et al. 2010).

In Norway, the centralization of population from the periphery to larger centers and from the north to the south has been the demographic trend for several decades, resulting in an increasingly elderly population in rural communities as the younger generation migrates to towns and cities (Granås and Nyseth 2007). To understand how these trends are affecting community resilience, there is a need to look at how communities are actually responding to change, and we have chosen the village of Senja in northern Norway for this purpose.

\section{METHODS}

A mixture of five qualitative methods was applied in this research. Mixed methods in qualitative research (Alexander et al. 2008) was seen as the most appropriate way to gain insights into the social processes in the village. The methods employed in this study include in-depth, semi-structured interviews, document analyses, participant observation, and media searches. The main data collection took place from June 2009 to July 2010 during four field visits, of which the longest lasted one month.

In-depth interviews were carried out with 10 individuals in the village, who represent local civic organizations, local officials, tourism actors, engaged individuals, and industry. Interviewees were selected through a desk study by identifying key individuals and individuals holding key positions in local institutions such as the local government. Five of these were approached prior to visiting the village and agreed to be interviewed. Further interviewees were selected through snowballing methodology, i.e., key individuals were asked to name others who would be relevant to meet. Interviews were either audio recorded and transcribed, or recorded by note writing. An interview guide was used to ensure that the same themes were covered in all the interviews. Interviewees were asked about their attachment to place, what they valued about the place, the community activities they take part in, their relationship to the natural environment and, in particular, what makes it a good place to live. Further they were asked about what changes they have observed and were prompted to talk about social, economic, political, weather, and climatic conditions. They were challenged on what the consequences of these changes might be and how they envisaged the future for the village.

The four visits to the village allowed for participant observation of local events, activities, and voluntary engagement in the village. Participant observation included attendance at various seminars, gatherings, and meetings in relation to village development processes and projects, as well as taking part in everyday activities in the municipalities. 
During fieldwork, a number of informal meetings with local officials and others took place, which helped contextualize information gained through the interviews.

Various internet and archive searches of municipal websites and regional government websites, as well as tourism industry and activities were undertaken as part of our work. The information sources include policy documents, project documents, statistics, and continuous newspaper search over two years, from September 2009 to June 2011, by A-tekst (a newspaper archive service). The documents and newspaper articles gave insight into recent processes of change, the relevant actors in the village, and how changes had been dealt with.

The data were analyzed with the help of the text analysis software QSR NVivo8, by coding according to themes. NVivo is a program which allows for structuring and analyzing text through coding and word-frequency searches. The data from the interviews were grouped, coded, and analyzed. The codes were made based on the interview guide, but as the analyses of the text developed, new codes were added. Through the analyses and literature review of community resilience research (Buikstra et al. 2010, Magis 2010, and Ross et al. 2010 were found particularly relevant), six dimensions of community resilience, presented in this article, were found to be particularly applicable to this village.

\section{COMMUNITY RESILIENCE IN A VILLAGE ON THE ISLAND OF SENJA}

The local context is necessary to understand how a community is dealing with challenges. Aspects of well-being and viability of the village were the main concerns among interviewees. This is comparable to research findings from other Arctic communities and in Australia (Hovelsrud and Smit 2010, Petheram et al. 2010). The main challenge for the village in this study was seen as population decline given a combination of outmigration and negative birth rates. The village has a population of 197, and the municipality as a whole has 907 inhabitants (Statistics Norway 2011). Since 1980, the population in the village has decreased from 350 people to 197 people in 2011 (see Fig. 2). The village is relatively homogenous; however, since the completion of the fieldwork this has slightly changed with the settlement of 20 refugees from Africa. The Sámi as a cultural group is not present in this village, although archaeological research indicates Sámi settlements in the area in the Middle Ages (Svestad 1995).

These demographic and related challenges led the local municipality to initiate a local development project, funded over three years (2007-2010) by the Ministry of Local Government and Regional Development. The aims of the project were to create new developments and a positive outlook in the municipality, in particular to attract new or returning inhabitants; to create new jobs; and to portray an active and forward looking society (Berg kommune 2007).
These aims are interlinked, as people in the village are leaving or not returning after acquiring higher education because they cannot find employment relevant to their qualifications.

Fig. 2. Population numbers for the village of Senja, from 1980-2011.

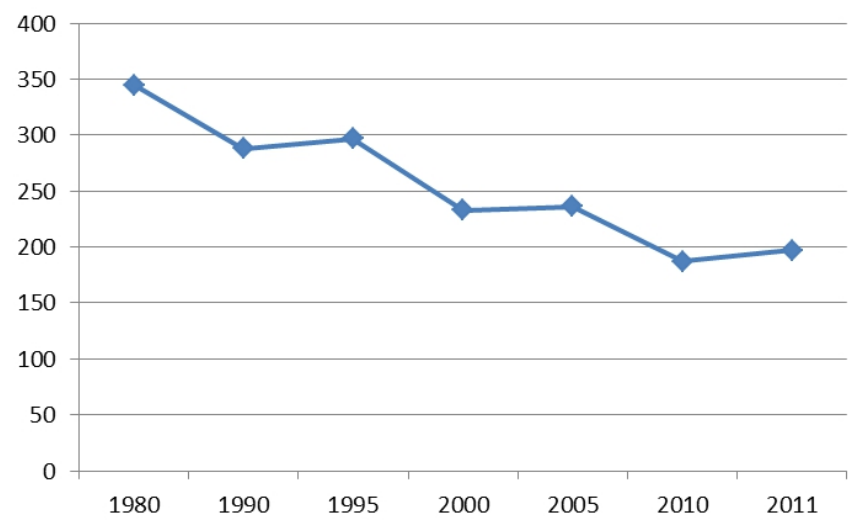

$\uparrow$ Note: no data was available for 1985.

$\ddagger$ Source: Statistics Norway.

This municipal project and other activities in the village exemplify the application of dimensions of community resilience. This Norwegian study draws on Buikstra et al. (2010), Magis (2010) and Ross et al. (2010), representing pioneering research that identifies and analyzes the various components of community resilience. The analysis of empirical material from this Norwegian village resulted the identification of six dimensions of community resilience in this particular context, which to a large degree correspond to the findings of earlier studies (Buikstra et al. 2010, Magis 2010, Ross et al. 2010), but with both added dimensions and with varying significance. This shows that each dimension may play different roles in different contexts with implications for adaptation policies and approaches.

The six dimensions found to be relevant for community resilience in this village are listed in Table 2 and elaborated on in the text below. These corroborate both analyses of the empirical material from the village and the above-cited literature (Buikstra et al. 2010, Magis 2010, and Ross et al. 2010).

\section{Community resources}

Resources are the foundation of community resilience. The available resources, whether human, social, cultural, political, economic, or natural, (Flora et al. 2004) and the ways in which these are engaged in a community, affect community resilience (Magis 2010). The village of Senja is "resourceful" with respect to human engagement and creativity, natural resources, natural environment, available jobs (low unemployment), organized activities for children and adults, cultural events, and public services. 
Table 2. Dimensions of community resilience.

\begin{tabular}{ll}
\hline \hline $\begin{array}{l}\text { Community resources, and the development and engagement of } \\
\text { these }\end{array}$ & $\begin{array}{l}\text { Includes human, social, natural, political, cultural, economic resources, and the way } \\
\text { in which these are made use of in a community }\end{array}$ \\
$\begin{array}{l}\text { Community networks } \\
\text { Institutions and services } \\
\text { People-place connections }\end{array}$ & $\begin{array}{l}\text { Including formal and informal organizations, rules in use, norms, and values } \\
\text { People's attachment to place which influences their local engagement. Places } \\
\text { represent history, past experiences, culture, traditions, and landscapes. }\end{array}$ \\
Active agents & $\begin{array}{l}\text { Individuals who take on an active role and show strong engagement in community } \\
\text { activities. The leadership portrayed by active agents is not necessarily linked to } \\
\text { formal appointments. } \\
\text { Learning from experiences and acting on this knowledge, single- and double-loop } \\
\text { learning. }\end{array}$ \\
\hline
\end{tabular}

The villagers are engaging the human resources that are available to them and take on responsibilities to increase wellbeing and social cohesion. As one interviewee noted, "There are a lot of things that are sad here, but at the same time you can see that people have such a strong will, people are really strong." A small population requires active involvement from a large proportion of the inhabitants and people contribute in the manner they are able when an event, activity, or festival is organized.

The natural resources in the village are particularly important in terms of employment. As one interviewee stated, "Of course we are dependent on exploiting the resources we are endowed with. It forms the basis for employment." The most important industries in the municipality as a whole are coastal fishing, mining, and tourism. In this village, employment in the graphite mine represented secure employment for a relatively long period of time. At the time of a devastating fire in 1985, the employment in the mine was 125 people. Today a new mine is in operation; however, it employs only 27 people. This considerable change in the key industry has had profound consequences for the way in which inhabitants view their future opportunities in the village. However, given the village population of 197 , the mine remains an important employer. The village previously had fisheries and fish-landing facilities, but the last professional fishing boats in this fjord were in the late 1970s. Today there are aquaculture installations. A major fishing harbor is located in a neighboring fjord. Currently the main employer is the public sector, and there is an emphasis on further developing tourism, which in particular promotes the natural environment (Amundsen 2012).

Interviewees noted that although they are rich in resources, they are struggling with population decline and low birth rates. The population trend presented in Fig. 1 clearly shows the downward trend in number of inhabitants. This was seen as the key factor that might reduce community resilience. Therefore, the village is promoting their resources to attract new inhabitants.

\section{Community networks}

Social networks were found in the study of Buikstra et al. (2010) to be the most prevalently mentioned dimension of community resilience. Ross et al. (2010) refer to community networks as activities and processes which support and build collaboration between people, and include community groups and level of volunteering. Here, community networks point specifically to ways in which various community groups and informal groupings constitute a support network that active agents know they can draw on to realize their ideas. Networks and social relations were noted as important for well-being. In the words of one interviewee, "It's the social relations that keep you in a community and contribute to well-being."

Many individuals in the village are strongly engaged in addressing the challenges of demographic change and local development. Community projects were established in two villages in the municipality, which were supported by the larger municipal project. Activities included marking hiking trails providing historical information for both residents and visitors, to strengthen local identity and attachment to place; building a marina for recreation and tourism purposes; and building a shelter ("gapahuk") in the hillside above the village, where residents gather for a coffee or other social activities. These activities have largely taken place on a voluntary basis, but with support from the municipality. The voluntary engagement may ensure the continuation of activities after the completion of the financed municipal project. Although the continuation of activities is not dependent on external funding, the loss of a paid position for local development in the municipality reduces the ways in which the local government can contribute in the process. However, population numbers have continued to decline despite these initiatives.

Community resilience was tested in the village when the local school was closed. However, it was noted that: "When things like this happen, things that could be considered a crisis, it has the effect of uniting people and this gives an opportunity to develop with more strength." The renewed strength to take action resulted in the establishment of a network that was 
appointed by the villagers to take forward their ideas for community development. This network was formed with the particular aim of improving or developing the village with respect to both concrete and visible infrastructure projects, such as building the marina, and initiating and supporting cultural activities. The network was also supportive in reopening the school.

\section{Institutions and services}

The concept of the "institution" is one with myriad usages; in this context, institutions include formal and informal organizations, and rules in use, norms, and values (North 1990). Some of the key institutions in the village are public institutions such as the school, nursery, post office, and local government administration offices; commercial services such as a grocery store; and community values about the importance of contributing to voluntary activities, such as what is termed "dugnad," or voluntary community work.

In the context of this village, service functions such as the post office and the grocery store, have a broader importance than the actual services they are providing. They are important aspects of the social fabric; they are meeting places, and there is a sense that without them, it would not be possible for the village to thrive. The fact that there is a distance of $65 \mathrm{~km}$ across a mountain to the next town also underlines the importance of these institutions and services to the village.

"Dugnad" is a particularly important informal institution, and tasks undertaken on "dugnad" typically include the amelioration of green communal spaces, and the renovation of community buildings such as a sports club house and a nursery. Participating in "dugnad" is expected of villagers, and more than the job that gets done, it is about building networks and social relations whilst contributing to the village. The village prides itself on high involvement of residents in volunteering, and one example is the organization of festivals, with themes such as music, art, fish, sports, and outdoor recreation. The uniqueness of place is used to attract both performers and audiences, as in many other communities in rural Norway (Førde and Borch 2010). These festivals make the residents proud because they are well organized, and are run on a voluntary basis, drawing on community networks to realize them.

Despite a high level of voluntary engagement, several interviewees questioned whether "dugnad" as an institution was disappearing. One individual in the village noted: "We have a lot of fun when we get together for a dugnad. It is a little difficult to get people to come, increasingly so. But this year we've had several dugnad at the sports club house and other places, and people have been very involved and a lot of people have participated."

Villagers were concerned that the loss of any of the key institutions and services would signify the end of a thriving village. The prime example was losing the local school, which the villagers themselves then reopened as a private school. Interviewees considered it likely that without the school, the nursery would be the next institution to disappear, which, in turn, would make it unattractive for families to settle in the village. In a similar position is the local store, run by a couple who are intent on doing their part to keep key institutions in the village.

As a formal institution, the active involvement of the local government, referred to by Ross et al. (2010) as "engaged governance," is instrumental in achieving outcomes from local development processes. The municipality contributed resources to initiate and facilitate local development activities, and provided legitimacy to these processes in the capacity of being a formal institution. For instance, in the process of reopening the closed school, the local government made the old school buildings available cheaply for the organization which reopened the private school in its place.

\section{People-place connections}

In the village of Senja, attachment to place is considered a strong driver of adaptation (Amundsen 2012). As Geertz (1996) states, places are usually meaningful to people living there. In the same way as Ross et al. (2010) found that people in their case communities were strongly linked to their place, people in this village are strongly attached to the village and this is reflected in their commitment to respond to the challenges facing the village. This attachment includes the natural environment, the other residents, and cultural and historical connections to the village. Several of the activities that have been initiated to try and turn the demographic decline aim to increasing well-being and a sense of place. The aim is to make it possible to continue living in the village and to make it a good place to live. Their strong sense of place is exemplified in many of the initiatives undertaken by the inhabitants, such as reopening the school and engaging in voluntary activities. There is an understanding among local actors that place attachment is important for community resilience, and in agreement with Ross et al. (2010), enhancing community resilience means strengthening people-place connections.

\section{Active agents}

The "active agent" label was applied by Magis (2010) and includes individuals taking leadership based on the belief in the ability to create change. In Buikstra et al. (2010), this dimension is termed "leadership." Interestingly, this dimension is not prevalent as a dimension of community resilience in the study by Ross et al. (2010). Active agents are individuals who have the ability to act and make things happen, and the term refers to both formal and informal leadership roles, as well as to key individuals who do no assume leadership but are instrumental in creating change through their involvement in activities. 
Active agents in Norway are referred to as "ildsjel," a word which literally means "soul of fire." It is attributed to someone who has a burning commitment for their community. These are individuals who are strongly engaged in activities locally, and initiate and carry out activities for the benefit of their community, ranging from starting up festivals, to building community buildings, and starting up businesses. Their importance is often significant, and "ildsjeler" have been identified as one of four factors driving municipal climate adaptation in Norway (Dannevig et al., in press).

Initiatives are taken forward by active agents, and collaboration between various actors help realize the ideas. In the village of Senja, the building of the marina for leisure boating can be attributed to one person alone, who drew on his connections in the local government, businesses, and community. He was also instrumental in transforming the closed village school into a private school; is ensuring that the local grocery store continues; and is running a combined gallery and tourism information center. Therefore, in assuming leadership, he is maintaining or developing some of the key institutions in the community. His imaginative visions for the community are based on a positive attitude and he argues that someone needs to be in the forefront with ideas and activities, and once people see that ideas become reality, they will follow and the positive outlook in community will increase. He stated: "I see myself as a village optimist, what I do here is because of my love for this village." Buikstra et al. (2010) also find that a positive outlook is important for generating positive development. As such, optimism is both a driving factor and a sought outcome.

Within a small village such as this, several tasks are carried out by a select few, which increase the potential for fatigue among the most involved individuals. One interviewee stated that "People are pulling up their sleeves and try to make the most of the resources we have available. But the thing about small places is that it is very person dependent. It is vulnerable. Even if there are only a couple of people who do not have the energy to contribute, who you have been used to depend on, it gets harder for the rest."

\section{Learning}

A continued willingness and ability to learn is key component of resilience, particularly as future challenges may be different from past experiences (Adger et al. 2011, Berkes and Jolly 2001, Brown and Westaway 2011). Learning is understood as a continuous process informing adaptive management, using feedback from social-ecological systems (Berkes et al. 2003). Additionally, organizational and institutional learning at all levels and between levels are necessary to enhance resilience (O'Brien and O'Keefe 2010).

Buikstra et al. (2010) include formal and informal learning, and learning from experience, in their dimensions of resilience. Learning from experience and applying knowledge gained from experience is seen as important to building resilience (Lopez-Marrero and Tschakert 2011, Buikstra et al. 2010). Learning includes single- and double-loop learning. Single-loop learning is learning that takes place within the current discourse; whereas double-loop learning challenges the existing discourse and results in a change or transformation of it (Argyris and Schön 1978). Learning is also key in adaptive management, defined as "processes informed by iterative learning about ecosystems and earlier management successes and failures" (Tompkins and Adger 2004).

For learning to lead to change, reflexive capabilities of individuals and societies are necessary (Woodhill and Röling 1998). Society develops and responds to challenges through critically evaluating its own processes, and through having an insight into its own roles. Recent literature points to the importance of reflexivity in learning, including the continuous ability to learn (Adger et al. 2011). In this context, reflexivity involves the capacity to reflect on systems-level changes and their causes, and how these may affect the village. Reflexivity is present in the village in the sense of appreciating the necessity to enhance future resilience by acting to turn the negative demographic trend. One interviewee pointed to reflexivity as a necessary factor for successful developments in the village. He noted that development is linked to the ability to reflect critically on one's own role and to actualize it. This includes a self-awareness and self-inquiry that allows for learning and development through a process of trial and error. Success in overcoming challenges related to demographics in this village would be an expression of resilience related to a mindset of self-awareness and self-inquiry and the ability to critically reflect on these issues. Such a mindset enhances resilience to future changes at a deeper level than the other dimensions of resilience noted above.

Tschakert and Dietrich (2010) argue that learning tools, such as experimentation and innovation, must be improved to enhance resilience. Renewal, innovation, and creativity were seen by interviewees as factors needed to overcome the problem of demographic decline. Several open meetings were held in the village to encourage innovation and ideas for local development. One interviewee observed: "We need people who show initiative and have the will to try, to dare trying out new things and approaches." The closure of the local school was seen as a local crisis, and in reflecting on the process of reopening the school, one interviewee saw it as a test of community resilience and adaptability to change. When analyzing how the village dealt with this crisis, it was assessed by interviewees that the community grew stronger through their responses.

The dimensions of resilience presented in Table 2 above are enacted in this village through activities undertaken to respond to the demographic decline and, conversely, these activities are undertaken with view to enhancing and strengthening 
community resilience. Importantly, these dimensions are interlinked in the way in which they contribute to community resilience. For this village, people-place connections are important, and are an important driver of adaptations. This people-place connection is expressed by many of the active agents, who are drawing on their attachment to place to improve well-being, to foster innovation, and to make the village an attractive place to live. Place attachment is thus partially what motivates active agents to act, yet they cannot act without the foundation of the whole range of community resources, institutions, and community networks. As an added dimension, learning is key to responding to future challenges, particularly given that many of these are unknown. Reflexivity in responding to new challenges and surprises may also contribute to enhancing future resilience.

\section{COMMUNITY RESILIENCE AND FUTURE CLIMATE CHANGE}

The village of Senja is located in a region that experiences significant variability and fluctuations in the weather, and fierce storms are not uncommon. Concerning climate change, the expectation of warmer summers and shorter winter seasons is welcomed by many. Hence, climate change is not regarded a significant challenge by the interviewees in this community, although some individuals express concerns. Given the unresolved challenge of demographic decline, climate-change adaptation becomes secondary to this more prevalent challenge. The focus of the interviews in this village was mainly on current challenges and, as such, weather and climatic conditions did not receive much attention. This was also because the observed weather was perceived to be more or less within the natural range of variability. The sentiment is that "we can adapt—we have always adapted" (see West and Hovelsrud 2010). There is evidence in the literature that communities that are accustomed to large variations have a larger range of adaptation options available and are more resilient (Denevan 1983, Forbes et al. 2009). Thus, a community which perceives itself as resilient today expects to be resilient to future changes, through assuming that resilient communities also have a high adaptive capacity to meet future challenges. Yet the question is whether the ways in which communities have adapted in the past can be transferred to future challenges, especially with a view to the large systemic changes and the consequential impacts that are projected (IPPC 2007). Climate change will have to be adapted to in combination with related challenges, and there are significant uncertainties related to these cumulative impacts that future societies will be required to adapt to (McCarthy and Martello 2005, O'Brien et al. 2004a, Wilbanks and Kates 2010). In light of this, it is questionable whether the dimensions that are important for community resilience today will be relevant for future resilience, and it may not be the case that resilient communities will be better at adapting to climate change.
There are two aspects that are particularly important with respect to understanding resilience today and in the future. The first is to analyze whether current resilience lead to complacency, creating a barrier to proactive adaptation to climate change. O'Brien et al. (2006) question complacency in the context of climate change impacts in Norway, and argue for a systemic and contextual approach to adaptation planning which can highlight particular vulnerabilities necessitating proactive adaptation. Communities in northern Norway are accustomed to relying on learning from experience in adapting to challenges. However, it is unknown whether the resilience that these communities are used to relying on prevents a proactive approach to adapting to future challenges. Hastrup (2009) argues that in addition to a practical flexibility to avoid a future threat, conceptual flexibility is needed, i.e., a perception that threats are dynamic and variable. In the context of climate change, this can be seen in light of perceptions of change and how it affects communities. Climate change is difficult to comprehend as a threat, since to many it is incomprehensible what impacts a changed climate could have on their community.

The second aspect of understanding resilience is whether the dimensions of community resilience that are found relevant today may or not be relevant in the future. Values change, new institutions arise, and goals of communities may be different. For future resilience, it may not be sufficient to have strong institutions, a seemingly stable natural resource base, a closeknit community with strong community networks, and engaged individuals. It is likely that dimensions other than those found relevant today may become more prevalent for future resilience. Dimensions of community resilience, such as a diverse and innovative economy (Ross et al. 2010) and livelihood flexibility (Hovelsrud et al. 2010), were not prevalent in this study but may become important for future resilience.

The three properties of a resilient SES are: (1) the amount of stress the system can undergo while still retaining the same function and structure, (2) the ability to self-organize, and (3) the capacity to adapt and learn (Berkes and Jolly 2001). In particular, the ability to self-organize and the capacity to adapt and learn are properties which can have implications for future community resilience. Goldstein (2008) gives an example of how a community self-organized when faced with a disaster, and depicted their ability to create new organizations when established organizations were slow in terms of responding to the disaster at hand. Goldstein notes that, although the created network was abandoned after the governmental agencies entered the scene, the learning which ensued and the awareness of the community's ability to self-organize when needed were important long-term outcomes.

Learning, and particularly reflexivity in learning, that is, the ability to assume and appreciate one's own role in causing and 
responding to changes, is a crucial dimension of community resilience. Learning may prove to be particularly relevant in adapting to challenges which depends on processes of multiple factors at interlinked scales. As noted by Anderies and Jansson (2011), local communities are affected by processes at national and global scales because of interlinked systems. Projected changes in climate, combined with increased connections with global processes, affect the room to maneuver locally, and these global interlinkages affects independence. As a way to overcome this, Adger et al. (2011) suggest continuous learning and a consideration of the interlinkages of various scales in developing policy responses. This is likely to be important in responding to future challenges and building future resilience.

\section{CONCLUSION}

These reflections contribute to the understanding of community resilience. Resilience is receiving increased attention, especially in the context of preparing for and responding to climate change, and it seen as critical for communities to stand better prepared for future challenges, including climate change. The specific context of a coastal village in northern Norway creates a particular kind of community resilience, yet the findings from this research are applicable to communities elsewhere, exemplified by the many overlapping dimensions of community resilience found in studies undertaken in Australia (Buikstra et al. 2010, Ross et al. 2010) and the Unites States (Magis 2010).

Six dimensions of community resilience were found to be relevant to the village studied in northern Norway through an analysis of responses to the local challenges. These dimensions-community resources, community networks, institutions and services, people-place connections, active agents, and learning (Table 2) - are activated in processes and activities in the village to respond to current challenges. These processes and activities are initiated to increase optimism and well-being, with the expectation that this, in turn, will lead to establishment of new jobs and increase the number of inhabitants, and ultimately enhance resilience. Many of these local activities are interlinked and seek to strengthen the identity of the place and make inhabitants more aware and proud of their place. It is the combination and interaction of the various dimensions of community resilience together which shapes community resilience.

The uncertainties about direct and indirect consequences of changes in climate and other factors make it difficult to define which dimensions will be important for resilience to future changes. The dimensions discussed here may or may not be relevant in adapting to future changes. Thus, it is important to enhance the understanding of resilience to include dimensions such as people-place connections (Ross et al. 2010), and other subjective factors (Brown and Westaway 2011), and to include reflexivity and learning in seeking to enhance resilience and in developing adaptation policies.
Transformation, i.e., the alteration of the system and moving to a new state, is increasingly discussed within the context of climate change impacts (Armitage and Plummer 2010, Nelson 2011, Olsson et al. 2004, Pelling 2011, Walker et al. 2004). Transformation is integral to the concept of resilience and the adaptive cycle (e.g., see Folke 2006, Gunderson and Holling 2002), and there is a recognition that the current changes in the SES are of such a magnitude that transformation (on a large scale) is necessary or even inevitable (Pelling 2011). A related discussion concerns how current or perceived resilience might cause systems to remain in an undesirable state (Nelson et al. 2007). In the context of climate change adaptation, the perceived current and future resilience could potentially explain why there are few examples of proactive adaptation to climate change (West and Hovelsrud 2010). Therefore, whether resilience is necessarily positive in the context of large systemic changes needs to be discussed (Nelson et al. 2007). It could be asserted that transformation is needed, more than adaptation (Pelling 2011). In fact, a deliberate transformation that actively seeks to create alternative futures, beyond the current approach of developing adaptations to projected changes, has been suggested (O'Brien 2012). A focus for future research could be an investigation of how learning processes can contribute to such a deliberative transformation.

A perception of current resilience can lead to complacency, resulting in inaction or maladaptation. Although communities may consider themselves resilient to today's challenges, projected systemic changes brought about by multiple interacting processes, and in particular, climate change, makes it difficult to assume resilience in the future. In an interlinked world, changes affect all levels, from small villages to the global. For the village discussed here, the globalized commodity markets of minerals and fisheries and the consequences of changes in these are well understood locally. Other changes, such as global environmental change, are not felt or are unknown and represent something intangible which is difficult to respond to and prepare for. It is not uncommon to be in a reactive "wait and see" mode (Gupta et al. 2010), as such reflexive learning emerges as crucial. Unless communities actively engage in reflexive learning processes about the causes of systemic changes and the links between local and global processes, there is a risk that community resilience becomes nothing more than an illusion. 
Responses to this article can be read online at: http://www.ecologyandsociety.org/issues/responses. $\mathrm{php} / 5142$

\section{Acknowledgments:}

This study was funded by the Research Council of Norway through the project ACTOR (Arctic Climate Change, Tourism, and Outdoor Recreation), which is part of the programme NORKLIMA - Climate change and impacts in Norway. The author especially wishes to thank members of Berg municipality and the village of Skaland in particular, who participated and contributed to this research. Karen O'Brien, Grete K. Hovelsrud and two anonymous reviewers provided valuable comments to the development of this paper. Bob van Oort and Bård Romstad helped with the graphics.

\section{LITERATURE CITED}

Adger, W. N. 2006. Vulnerability. Global Environmental Change 16:268-81.

Adger, W. N., K. Brown, D. Nelson, F. Berkes, H. Eakin, C. Folke, K. Galvin, L. Gunderson, M. Goulden, K. L. O'Brien, J. Ruitenbeek, and E. L. Tompkins. 2011. Resilience implications of policy responses to climate change. Wiley Interdisciplinary Reviews: Climate Change 2:757-766. http:// dx.doi.org/10.1002/wcc.133

Alexander, V., H. Thomas, A. Cronin, J. Fielding, and J. Moran-Ellis. 2008. Mixed methods. Pages 125-144 in N. Gilbert, editor. Researching social life. Third edition. Sage, London, UK.

Amundsen, H. 2012. Differing discourses of development in the Arctic: the case of nature-based tourism in northern Norway. The Northern Review 35:125-146.

Amundsen, H., F. Berglund, and H. Westskog. 2010. Overcoming barriers to climate change adaptation-a question of multilevel governance? Environment and Planning C: Government and Policy 28:276-289. http://dx. doi.org/10.1068/c0941

Anderies, J., and M. A. Janssen. 2011. The fragility of robust social-ecological systems. Global Environmental Change 21:1153-1156. http://dx.doi.org/10.1016/j.gloenvcha.2011.07.004

Anisimov, O. A., D. G. Vaughan, T. V. Callaghan, C. Furgal, H. Marchant, T. D. Prowse, H. Vilhjálmsson, and J. E. Walsh. 2007. Polar regions (Arctic and Antarctic). Pages 653-685 in M. L. Parry, O. F. Canziani, J. P. Palutikof, P. J. Van Der Linden, and C. E. Hanson, editors. Climate change 2007: impacts, adaptation and vulnerability. Contribution of
Working Group II to the Fourth Assessment Report of the Intergovernmental Panel on Climate Change. Cambridge University Press, Cambridge, UK.

Arctic Climate Impact Assessment (ACIA). 2005. Arctic climate impact assessment scientific report. Cambridge University Press, Cambridge, UK.

Arctic Council. 2004. Arctic human development report. Cambridge University Press, Cambridge, UK; Stefansson Arctic Institute, Akureyri, Iceland.

Arctic Monitoring and Assessment Programme (AMAP). 2011a. Snow, water, ice and permafrost in the Arctic (SWIPA): executive summary. AMAP, Oslo, Norway.

Arctic Monitoring and Assessment Programme (AMAP). 2011b. Snow, water, ice and permafrost in the Arctic (SWIPA): climate change and the cryosphere. AMAP, Oslo, Norway.

Argyris, C., and D. Schön. 1978. Organizational learning: a theory of action perspective. Addison Wesley, Reading, Massachusetts, USA. http://dx.doi.org/10.2307/40183951

Armitage, D., and R. Plummer, editors. 2010. Adaptive capacity and environmental governance. Springer, Heidelberg, Germany. http://dx.doi.org/10.1007/978-3-642-12194-4

Belliveau, S., B. Smit, and B. Bradshaw. 2006. Multiple exposures and dynamic vulnerability: evidence from the grape industry in the Okanagan Valley, Canada. Global Environmental Change 16:364-378. http://dx.doi.org/10.1016/ j.gloenvcha.2006.03.003

Berg kommune. 2007. God-Nar og raus-småsamfunnssatsing i Berg kommune. Skaland, Berg kommune, Norway.

Berkes, F., J. Colding, and C. Folke, editors. 2003. Navigating social-ecological systems: building resilience for complexity and change. Cambridge University Press, Cambridge, UK.

Berkes, F. and D. Jolly. 2001. Adapting to climate change: social-ecological resilience in a Canadian western Arctic community. Conservation Ecology 5:18.

Bjørnå, H., and N. Aarsæther. 2010. Networking for development in the north: power, trust, and local democracy. Environment and Planning C 28:304-317. http://dx.doi. org/10.1068/c0942

Brown, K., and E. Westaway. 2011. Agency, capacity, and resilience to environmental change: lessons from human development, well-being, and disasters. Annual Review of Environment and Resources 36:321-42. http://dx.doi. org/10.1146/annurev-environ-052610-092905

Buikstra, E., H. Ross, C. A. King, P. G. Baker, D. Hegney, K. Mclachlan, and C. Rogers-Clark. 2010. The components of 
resilience: perceptions of an Australian rural community. Journal of Community Psychology 38:975-991. http://dx.doi. org/10.1002/jcop.20409

Chapin, F. S., G. Peterson, F. Berkes, T. V. Callaghan, P. Anglestam, M. Apps, C. Beier, Y. Bergeron, A. -S. Crépin, K. Danell, T. Elmqvist, C. Folke, B. Forbes, N. Fresco, G. Juday, J. Niemelä, A. Shvidenko, and G. Whiteman. 2004. Resilience and vulnerability of northern regions to social and environmental change. Ambio 33:344-349.

Coulthard, S. 2012. Can we be both resilient and well, and what choices do people have? Incorporating agency into the resilience debate from a fisheries perspective. Ecology and Society 17(1):4. http://dx.doi.org/10.5751/ES-04483-170104

Crate, S. 2008. Gone the bull of winter? Grappling with the cultural implications of and anthropology's Role(s) in global climate change. Current Anthropology 49:569-595. http://dx. doi.org/10.1086/529543

Dannevig, H., G. K. Hovelsrud, and I. Husabø. In press. Driving the agenda for climate change adaptation in Norwegian municipalities. Environment and Planning $C$.

Denevan, W. M. 1983. Adaptation, variation and cultural geography. The Professional Geographer 35:399-407. http:// dx.doi.org/10.1111/j.0033-0124.1983.00399.x

Flora, C. B., J. L. Flora, and S. Fey. 2004. Rural communities: legacy and change. Second edition. Westview, Boulder, Colorado, USA.

Folke, C. 2006. Resilience: the emergence of a perspective for social-ecological systems analysis. Global Environmental Change 16:253-267. http://dx.doi.org/10.1016/j.

gloenvcha.2006.04.002

Forbes, B., F. Stammler, T. Kumula, N. Meschtyb, A. Pajunen, and E. Kaarlejärvi. 2009. High resilience in the Yamal-Nenets social-ecological system, West Siberian Arctic, Russia. Proceedings of the National Academy of Sciences of the United States of America 106:22041-22048. http://dx.doi.org/10.1073/ pnas.0908286106

Ford, J. D., B. Smit, and J. Wandel. 2006a. Vulnerability to climate change in the Arctic: a case study from Arctic Bay, Canada. Global Environmental Change 16:282-292. http:// dx.doi.org/http://dx.doi.org/10.1016/j.gloenvcha.2005.11.007

Ford, J. D., B. Smit, J. Wandel, and J. Macdonald. $2006 b$. Vulnerability to climate change in Igloolik, Nunavut: what can we learn from the past and present. Polar Record 42:127138. http://dx.doi.org/http://dx.doi.org/10.1017/S0032247406005122

Førde, A. and O. J. Borch, editors. 2010. Innovative Bygdemiljø. Ildsjeler og nyskapningsarbeid. Bergen, Fagbokforlaget, Norway.
Førland, E. J., E. Alfnes, H. Amundsen, R. P. Asvall, R. Benestad, J. Debernard, T. Engen-Skaugen, I. Hanssen-Bauer, K. Harstveit, J. E. Haugen, G. K. Hovelsrud, K. Isaksen, C. Jaedicke, K. Kronholm, S. Kvambekk, A, J. Lacasce, L. A. Roald, K. Sletten, and K. Stalsberg. 2007. Climate change and natural disasters in Norway: an assessment of possible future changes. Norwegian Meteorological Institute, Oslo, Norway.

Geertz, C. 1996. Afterword. Pages 193-197 in S. Feld, and K. H. Basso, editors. Senses of place. School of American Research Advanced Seminar Series, Santa Fe, New Mexico, USA. http://dx.doi.org/10.1017/CBO9780511975158.011

Goldstein, B. E. 2008. Skunkworks in the embers of the cedar fire: enhancing resilience in the aftermath of disaster. Human Ecology 36:15-28. http://dx.doi.org/10.1007/s10745-007-9133-6

Government of Norway. 2009. Political platform as basis for the government's work 2009-2013. Soria Moria, Norway. [online] URL: http://www.regjeringen.no/upload/SMK/Vedlegg/ Rapporter/Plattform-sm2-a4-web-english.pdf

Granås, B., and T. Nyseth. 2007. Place reinvention in the north. Dynamics and governance perspectives. Nordic research programme 2005-2008. Nordregio, Stockholm, Sweden.

Gunderson, L. H., and C. S. Holling, editors. 2002. Panarchy: understanding transformations in human and natural systems. Island Press, Washington, D.C., USA.

Gupta, J., C. Termeer, J. Klostermann, S. Meijerink, M. Van Den Brink, P. Jong, S. Nooteboom, and E. Bergsma. 2010. The adaptive capacity wheel: a method to assess the inherent characteristics of institutions to enable the adaptive capacity of society. Environmental Science and Policy 13:459-471. http://dx.doi.org/10.1016/j.envsci.2010.05.006

Hastrup, K. 2009. Waterworlds: framing the question of social resilience. Pages 11-30 in: K. Hastrup, editor. The question of resilience: social responses to climate change. The Danish Royal Academy of Science and Letters, Copenhagen, Denmark.

Hovelsrud, G. K., H. Dannevig, J. J. West, and H. Amundsen. 2010. Adaptation in fisheries and municipalities: three communities in northern Norway. Pages 23-62 in: G. K. Hovelsrud and B. Smit, editors. Community adaptation and vulnerability in Arctic regions. Springer, Dordrecht, The Netherlands. http://dx.doi.org/10.1007/978-90-481-9174-1_2

Hovelsrud, G. K., and B. Smit, editors. 2010. Community adaptation and vulnerability in Arctic regions. Springer, Dordrecht, The Netherlands. http://dx.doi.org/10.1007/978-90-481-9174-1

Hovik, S., and M. Reitan. 2004. National environmental goals in search of local institutions. Environment and Planning $C$ 22:687-699. http://dx.doi.org/10.1068/c0302j 
Intergovernmental Panel on Climate Change (IPCC). 2007. Climate change 2007: impacts, adaptation and vulnerability. Contribution of Working Group II to the Fourth Assessment Report of the Intergovernmental Panel on Climate Change. Cambridge University Press, Cambridge, UK.

Keskitalo, E. C. H. 2004. Vulnerability and adaptive capacity in forestry, fishing and reindeer-herding systems in northern Europe. Pages 262-266 in Arctic Climate Impact Assessment (ACIA) International Symposium on Climate Change in the Arctic. 9-12 November, 2004. University of Iceland, Reykjavik, Iceland.

Keskitalo, E. C. H. 2008. Vulnerability and adaptive capacity in forestry in northern Europe: a Swedish case study. Climatic Change 87:219-234. http://dx.doi.org/10.1007/s10584-007-9337-1

Kommunal-og Departmentet (KRD). 2009. Local growth and hope for the future: the rural and regional policy of the Norwegian government. Summary of White Paper No. 25 (2008-2009). Norwegian Ministry of Local Government and Regional Development, Oslo, Norway.

Krupnik, I., and D. Jolly, editors. 2002. The earth is faster now: indigenous observations of Arctic environmental change. Arctic Research Consortium of the United States, Fairbanks, Alaska, USA.

Leichenko, R. M., and K. O'Brien. 2008. Environmental change and globalization: double exposures. Oxford University Press, New York, New York, USA. http://dx.doi. org/http://dx.doi.org/10.1093/acprof:oso/9780195177329.001.0001

Lopez-Marrero, T., and P. Tschakert. 2011. From theory to practice: building more resilient communities in flood-prone areas. Environment and Urbanization 23:229-249. http://dx. doi.org/10.1177/0956247810396055

Luthar, S. S., and D. Cicchetti. 2000. The construct of resilience: implications for interventions and social policies. Development and Psychopathology 12:857-885. http://dx. doi.org/10.1017/S0954579400004156

Magis, K. 2010. Community resilience: an indicator of social sustainability. Society and Natural Resources 23:401-416. http://dx.doi.org/10.1080/08941920903305674

Manyena, S. B. 2006. The concept of resilience revisited. Disasters 30:433-450. http://dx.doi.org/10.1111/ j.0361-3666.2006.00331.x

McCarthy, J., and M. L. Martello. 2005. Climate change in the context of multiple stressors and resilience. Pages 945988 in Impacts of a warming Arctic: Arctic climate impact assessment. Cambridge University Press, Cambridge, UK.

Nelson, D., W. N. Adger, and K. Brown. 2007. Adaptation to environmental change: contributions of a resilience framework. Annual Review of Environment and Resources
32:395-419. http://dx.doi.org/10.1146/annurev. energy.32.051807.090348

Nelson, D. R. 2011. Adaptation and resilience: responding to a changing climate. Wiley Interdisciplinary Reviews: Climate Change 2:113-120. http://dx.doi.org/10.1002/wcc.91

Norris, F. H., S. P. Stevens, B. Pfefferbaum, K. F. Wyche, and R. L. Pfefferbaum. 2008. Community resilience as a metaphor, theory, set of capacities, and strategy for disaster readiness. American Journal of Community Psychology 41:127-150. http://dx.doi.org/10.1007/s10464-007-9156-6

North, D. C. 1990. Institutions, institutional change and economic performance. Cambridge University Press, Cambridge, UK. http://dx.doi.org/10.1017/CBO9780511808678

O'Brien, G., and P. O'Keefe. 2010. Resilient responses to climate change and variability: a challenge for public policy. International Journal of Public Policy 6:369-385. http://dx. doi.org/10.1504/IJPP.2010.035136

O'Brien, K. 2012. Global environmental change II: from adaptation to deliberate transformation. Progress in Human Geography. 36(5):667-676. http://dx.doi.org/http://dx.doi. org/10.1177/0309132511425767

O’Brien, K., S. Eriksen, L. Sygna, and L. O. Næss. 2006. Questioning complacency: climate change impacts, vulnerability, and adaptation in Norway. Ambio 35:50-56. http://dx.doi.org/10.1579/0044-7447(2006)35[50:QCCCIV]2.0. $\mathrm{CO} ; 2$

O'Brien, K., R. Leichenko, U. Kelkar, H. Venema, G. Aandahl, H. Tompkins, A. Javed, S. Bhadwal, S. Barg, L. Nygaard, and J. West. 2004a. Mapping vulnerability to multiple stressors: climate change and globalization in India. Global Environmental Change: Human and Policy Dimensions 14:303-313. http://dx.doi.org/http://dx.doi.org/10.1016/ j.gloenvcha.2004.01.001

O'Brien, K., L. Sygna, and J. Haugen. 2004b. Vulnerable or resilient? A multi-scale assessment of climate impacts and vulnerability in Norway. Climatic Change 64:193-225. http:// dx.doi.org/http://dx.doi.org/10.1023/B:CLIM.0000024668.70143.80

O'Brien, K., and J. Wolf. 2010. A values-based approach to vulnerability and adaptation to climate change. Wiley Interdisciplinary Reviews: Climate Change 1:232-242.

Olsson, P., C. Folke, and T. Hahn, T. 2004. Social-ecological transformation for ecosystem management: the development of adaptive co-management of a wetland landscape in southern Sweden. Ecology and Society 9(4): 2. [online] URL: http:// www.ecologyandsociety.org/vol9/iss4/art2/

Orlove, B. S. 2009. The past, the present and some possible futures of adaptation. Pages 131-163 in W. N. Adger, I. Lorenzoni, and K. O'Brien, editors. Adapting to climate 
change: thresholds, values, governance. Cambridge University Press, Cambridge, UK. http://dx.doi.org/10.1017/ $\underline{\text { CBO9780511596667.010 }}$

Pedersen, H. 2008. Ny havressurslov-et tidsskille $i$ forvaltningen av viltlevende marine ressurser. Ministry of Fisheries and Coastal Affairs, Government of Norway, Oslo, Norway.

Pelling, M. 2011. Adaptation to climate change: from resilience to transformation. Routledge, London, UK.

Petheram, L., K. K. Zander, B. M. Campbell, C. High, and N. Stacey. 2010. "Strange changes:" indigenous perspectives of climate change and adaptation in NE Arnhem Land (Australia). Global Environmental Change: Human and Policy Dimensions 20:681-692. http://dx.doi.org/http://dx. doi.org/10.1016/j.gloenvcha.2010.05.002

RegClim. 2005. RegClim: Norges klima om 100 år: Usikkerheter og risiko. Norwegian Meteorolgical Institute, Oslo, Norway.

Ross, H., M. Cuthill, K. Macklean, D. Jansen, and B. Witt. 2010. Understanding, enhancing and managing for social resilience at the regional scale: opportunities in North Queensland. Report to the Marine and Tropical Sciences Research Facility. Reef and Rainforest Research Centre Limited, Cairns, Australia.

Smit, B., and J. Wandel. 2006. Adaptation, adaptive capacity and vulnerability. Global Environmental Change 16:282-292. http://dx.doi.org/10.1016/j.gloenvcha.2006.03.008

Statistics Norway. 2011. Kommunefakta—nøkkeltall om kommunene. Oslo, Norway. [online] URL: http://www.ssb. no/kommune

Svestad, A. 1995. I fangstfolk og fiskeres fotefar: Mefjordvær. Fotefar mot nord. Troms $\emptyset$, Norway.

Tompkins, E. L., and W. N. Adger. 2004. Does adaptive management of natural resources enhance resilience to climate change? Ecology and Society 9(2): 10. [online] URL: http:// www.ecologyandsociety.org/vol9/iss2/art10/

Tschakert, P., and K. A. Dietrich. 2010. Anticipatory learning for climate change adaptation and resilience. Ecology and Society, 15(2): 11. [online] URL: http://www.ecologyandsociety. org/vol15/iss2/art11/

Tyler, N. J. C., J. M. Turi, M. A. Sundset, K. Strom Bull, M. N. Sara, E. Reinert, N. Oskal, C. Nellemann, J. J. McCarthy, S. D. Mathiesen, M. L. Martello, O. H. Magga, G. K. Hovelsrud, I. Hanssen-Bauer, N. I. Eira, I. M. G. Eira, and R. W. Corell. 2007. Saami reindeer pastoralism under climate change: applying a generalized framework for vulnerability studies to a sub-arctic social-ecological system. Global
Environmental Change 17:191-206. http://dx.doi.org/10.1016/ j.gloenvcha.2006.06.001

Walker, B., C. S. Holling, S. R. Carpenter, and A. Kinzig. 2004. Resilience, adaptability and transformability in socialecological systems. Ecology and Society 9(2): 5. [online] URL: http://www.ecologyandsociety.org/vol9/iss2/art5/

West, J. J., and G. K. Hovelsrud. 2008. Climate change in northern Norway. Toward an understanding of socioeconomic vulnerability of natural resource-dependent sectors and communities. CICERO Report 2008:04. Centre for International Climate and Environmental Research-Oslo (CICERO), Oslo, Norway.

West, J. J., and G. K. Hovelsrud. 2010. Cross-scale adaptation challenges in the coastal fisheries: findings from Lebesby, northern Norway. Arctic 63:338-354.

Wilbanks, T. J., and R. W. Kates. 2010. Beyond adapting to climate change: embedding adaptation in responses to multiple threats and stresses. Annals of the Association of American Geographers 100:1-10. http://dx.doi. org/10.1080/00045608.2010.500200

Woodhill, J., and N. G. Röling. 1998. The second wing of the eagle: the human dimension in learning our way to more sustainable futures. Pages 46-71 in N. G. Röling and M. A. E. Wagemakers, editors. Facilitating sustainable agriculture: participatory learning and adaptive management in times of environmental uncertainty. Cambridge University Press, Cambridge, UK. 